\title{
Evaluation of amplified rDNA restriction analysis (ARDRA) for the identification of Mycoplasma species
} Tim Stakenborg*1, Jo Vicca², Patrick Butaye ${ }^{1}$, Dominiek Maes², Thierry De Baere $^{3}$, Rita Verhelst ${ }^{3}$, Johan Peeters ${ }^{1}$, Aart de Kruif ${ }^{1}$, Freddy Haesebrouck ${ }^{2}$ and Mario Vaneechoutte ${ }^{3}$

Address: ${ }^{1}$ Veterinary and Agrochemical Research Centre, Groeselenberg 99, 1180 Brussels, Belgium, ${ }^{2}$ Faculty of Veterinary Medicine, Ghent University, Salisburylaan 133, 9820 Merelbeke, Belgium and ${ }^{3}$ Department of Clinical Chemistry, Microbiology \& Immunology, Ghent University Hospital, De Pintelaan 185, 9000 Ghent, Belgium

Email: Tim Stakenborg* - tista@var.fgov.be; Jo Vicca - Jo.Vicca@Ugent.be; Patrick Butaye - pabut@var.fgov.be; Dominiek Maes - Dominiek.Maes@Ugent.be; Thierry De Baere - Thierry.Debaere@UGent.be; Rita Verhelst - Rita.Verhelst@Ugent.be; Johan Peeters - jopee@var.fgov.be; Aart de Kruif - Aart.deKruif@Ugent.be; Freddy Haesebrouck - Freddy.Haesebrouck@Ugent.be; Mario Vaneechoutte - Mario.Vaneechoutte@UGent.be

* Corresponding author

Published: 14 June 2005

BMC Infectious Diseases 2005, 5:46 doi:10.1/86/147/-2334-5-46
Received: 23 February 2005

Accepted: 14 June 2005

This article is available from: http://www.biomedcentral.com/I47I-2334/5/46

(C) 2005 Stakenborg et al; licensee BioMed Central Ltd.

This is an Open Access article distributed under the terms of the Creative Commons Attribution License (http://creativecommons.org/licenses/by/2.0), which permits unrestricted use, distribution, and reproduction in any medium, provided the original work is properly cited.

\begin{abstract}
Background: Mycoplasmas are present worldwide in a large number of animal hosts. Due to their small genome and parasitic lifestyle, Mycoplasma spp. require complex isolation media. Nevertheless, already over 100 different species have been identified and characterized and their number increases as more hosts are sampled. We studied the applicability of amplified rDNA restriction analysis (ARDRA) for the identification of all I I6 acknowledged Mycoplasma species and subspecies.
\end{abstract}

Methods: Based upon available I6S rDNA sequences, we calculated and compared theoretical ARDRA profiles. To check the validity of these theoretically calculated profiles, we performed ARDRA on 60 strains of 27 different species and subspecies of the genus Mycoplasma.

Results: In silico digestion with the restriction endonuclease Alul (AG^CT) was found to be most discriminative and generated from 3 to 13 fragments depending on the Mycoplasma species. Although 73 Mycoplasma species could be differentiated using Alul, other species gave undistinguishable patterns. For these, an additional restriction digestion, typically with $B f a l$ ( $\mathrm{C}^{\wedge} \mathrm{TAG}$ ) or HpyFIOVI (GCNNNNN^NNGC), was needed for a final identification. All in vitro obtained restriction profiles were in accordance with the calculated fragments based on only one I6S rDNA sequence, except for two isolates of $M$. columbinum and two isolates of the $M$. mycoides cluster, for which correct ARDRA profiles were only obtained if the sequences of both rrn operons were taken into account.

Conclusion: Theoretically, restriction digestion of the amplified rDNA was found to enable differentiation of all described Mycoplasma species and this could be confirmed by application of ARDRA on a total of 27 species and subspecies. 


\section{Background}

Mycoplasmas are phylogenetically related to gram-positive bacteria with low GC-content and belong to the class of the Mollicutes. They form a unique group of bacteria that lack a cell-wall and that contain sterols in their cytoplasmatic membrane. They are of great importance, since several species are pathogenic to animals or humans, whereas species of other mollicute genera also infect plants and insects [1]. In addition, a series of mycoplasmas cause trouble in the laboratory, because they infect cell cultures. Already over 100 species have been described, and their number, as well as the number of different hosts is still increasing.

A correct identification of mycoplasmas, mostly performed after a fastidious initial isolation, may be achieved by various methods. Original tools to identify mycoplasmas were mainly based on biochemical and serological differentiation, varying from simple precipitation tests [2], to ELISA [3,4], immunofluorescence [5], or Western blot analysis [6]. These techniques are being replaced by faster DNA-based tools [7]. Many of these methods are based on the 16S rDNA sequence for various reasons. First, the 16S rDNA has been sequenced for all recognized Mycoplasma spp. and is required when describing a new species [8]. Secondly, the $16 \mathrm{~S}$ rDNA sequences have lower intraspecific variability than most protein encoding genes, hence their use in the construction of phylogenetic topologies [9]. Recently, denaturing gradient gel electrophoresis of amplified 16S rDNA was shown to be useful to differentiate most Mycoplasma spp. [10]. In another approach, correct identification of related Mycoplasma spp. was based on differences of the 16S-23S intergenic spacer (ITS) region. Both size variation [11] as sequence differences $[11,12]$ of the ITS were successfully used to differentiate related species. Compared to the 16S rDNA sequence, ITS sequences may vary more between strains of the same species due to a lower selection pressure [13], although reports of very highly conserved ITS regions are known as well [14].

Amplified rDNA restriction analysis (ARDRA) has already been used for the identification of some avian species [1517] as well as for pathogenic mycoplasmas in cats [18]. Restriction analysis with PstI of an amplified 16S rDNA fragment was also shown useful to differentiate M. capricolum subsp. capripneumoniae from the other species belonging to the mycoides-cluster [19]. The potential and power of ARDRA to identify members of the Mollicutes was already put forward [20], but was never worked out in detail for a large number of species. In this study, we investigated the value of ARDRA to identify all (to date) recognized Mycoplasma spp.

\section{Methods \\ Isolates}

A total of 60 strains, belonging to 27 different Mycoplasma species and subspecies, were used during this study (Table 1 ). The Mycoplasma spp. belonging to the mycoides-cluster and the M. hyosynoviae strains, were kindly provided as purified genomic DNA samples by Dr. L. Manso-Silivan (CIRAD, France) and Dr. B. Kokotovic (DFVF, Denmark), respectively. All other Mycoplasma spp. were cultivated using F-medium [21], modified Hayflick medium [22], SP-4-medium [22], SP-4-medium supplemented with Larginine, HS-medium [23], or Friis'-medium with ampicillin instead of methicillin [24].

All isolates were previously identified using biochemical tests and growth precipitation tests with absorbed rabbit antisera [2]. Whenever discrepancies existed between the obtained ARDRA-profiles and the serological results, the $16 \mathrm{~S}$ rDNA was sequenced for an exact identification [25].

\section{DNA extraction}

DNA of growing cultures was extracted using a phenolchloroform extraction described previously [26] or using alkaline lysis. For alkaline lysis, the cultures were centrifuged $(2 ', 10000 \mathrm{~g})$ and resuspended in $50 \mu \mathrm{l}$ lysis buffer $(0.25 \%$ SDS in $0.05 \mathrm{~N} \mathrm{NaOH})$. After $5^{\prime}$ at $95^{\circ} \mathrm{C}, 300 \mu \mathrm{l}$ water was added and the bacterial debris was centrifuged $(2 ', 10000 \mathrm{~g})$. One $\mu \mathrm{l}$ of the supernatant was used as template for amplification of the 16S rDNA.

\section{I6S PCR amplification}

The universal primers pA (5'AGAGTTTGATCCTGGCTCAG) and $\mathrm{pH}$ (5'AAGGAGGTGATCCAGCCGCA) were used to amplify the 16S rRNA genes [25], yielding an amplification product of approximately $1500 \mathrm{bp}$. Thirty cycles $\left(20^{\prime \prime} 94^{\circ} \mathrm{C} ; 15^{\prime \prime} 57^{\circ} \mathrm{C}\right.$; and $\left.30^{\prime} 72^{\circ} \mathrm{C}\right)$ were run on a GeneAmp 9600 Thermal Cycler (Perkin Elmer, USA) using $3 \mathrm{U}$ recombinant Taq DNA polymerase (Invitrogen, UK), $1 \times$ PCR buffer $\left(20 \mathrm{mM}\right.$ Tris-HCl, $1.5 \mathrm{mM} \mathrm{MgCl}_{2}$, and $50 \mathrm{mM} \mathrm{KCl} ; \mathrm{pH} 8.4), 10 \mathrm{pmol}$ of each primer and 1 $\mu \mathrm{l}$ of the genomic DNA ( $30 \mathrm{ng}$ ) as template. Reaction volumes were $50 \mu \mathrm{l}$.

\section{Restriction digestion}

For all 60 strains, $10 \mu \mathrm{l}$ of the $16 \mathrm{~S}$ rDNA PCR product was digested with $5 \mathrm{U}$ of restriction enzyme AluI (Fermentas, Lithuania; sequence: $\mathrm{AG}^{\wedge} \mathrm{CT}$ ) and the associated $\mathrm{Y}^{+} /$Tango restriction buffer (Fermentas) in a total volume of $20 \mu \mathrm{l}$ for 2 hours at $37^{\circ} \mathrm{C}$. For a final identification, the amplified 16S rDNA of some strains were digested in addition with $B f a \mathrm{I}$ (New England Biolabs, USA; sequence: $\mathrm{C}^{\wedge} \mathrm{TAG}$ ) or $H p y$ F10VI (Fermentas; sequence: GCNNNNN^NNGC). The restriction fragments were separated on a 3\% Nusieve 3:1 agar (Tebu-Bio, France) for 2 hours at $130 \mathrm{~V}$ and visualized using a GeneGenius gel documentation system 
Table I: List of strains used in this study

\begin{tabular}{|c|c|c|}
\hline Mycoplasma species & Number of strains & Strain designations \\
\hline M. agalactiae & 2 & NCTC 10123 (PG2); 5725 \\
\hline M. arginini & 1 & $884 / 200$ \\
\hline M. bovigenitalium & 1 & MNI20 \\
\hline M. bovirhinis & 3 & ATCC 27748; O475; CODA 8L \\
\hline M. bovis & 4 & 83/6I; 295VD; Widanka309; O422 \\
\hline M. capricolum subsp. capricolum & I & ATCC 27343 (California Kid) \\
\hline M. capricolum subsp. capripneumoniae & I & NCTC $10192(\mathrm{~F} 38)$ \\
\hline M. columbinasale & 1 & 397 \\
\hline M. columbinum & 4 & 423VD; 446; 447; 448 \\
\hline M. columborale & I & Pul46 \\
\hline M. dispar & 2 & ATCC 27I40; MdispA \\
\hline M. flocculare & 4 & ATCC 27399 (Ms42); MPI02; MflocF6A; MflocF3I6 \\
\hline M. gallinarum & 3 & MgalnA; D63P; MgalnB \\
\hline M. gallisepticum & 3 & ATCC 19610; A5969; 2000 Мус58 \\
\hline M. glycophilum & 2 & 4I2VD; MglyFIA \\
\hline M. hyopneumoniae & 4 & ATCC 25934 (J); MhF56C; MhF6I2D; MhF72C \\
\hline M. hyorhinis & 4 & MhyorF6A; MhyorF9A; MhyorF7A; MhyorFIA \\
\hline M. hyosynoviae & 4 & ATCC 2559I (SI6); Mp6; Mp96; Mpl78 \\
\hline M. lipofaciens & 1 & RI7I \\
\hline M. mycoides subsp. capri & i & $\mathrm{Pg} 3$ \\
\hline M. mycoides subsp. mycoides $L C$ & 1 & YG \\
\hline M. mycoides subsp. mycoides SC & 1 & $\mathrm{Pgl}$ \\
\hline M. neurolyticum & 2 & MneuFIA; WVUI853 \\
\hline M. orale & 1 & ATCC 23714 \\
\hline M. pneumoniae & 3 & 0696A, I285A, I284A \\
\hline M. putrefaciens & 4 & Put85; B387; B73I; 7578.95 \\
\hline Mycoplasma sp. bovine group 7 & 1 & $\mathrm{Pg} 50$ \\
\hline
\end{tabular}

(Westburg, The Netherlands). A 50-bp ladder was used as a DNA marker (Fermentas).

\section{Sequences \&in silico ARDRA-profiles}

ARDRA-profiles were calculated for all Mycoplasma spp. as acknowledged by the International Committee on Systematics of Prokaryotes (ICPS) to date. The 16S rDNA sequences were downloaded from Genbank (accession numbers are indicated in Figure 1). A consensus sequence was constructed and used for species for which more than one sequence was available. The $M$. orale $16 \mathrm{~S}$ rDNA sequence was determined and submitted [Genbank:AY796060], since the only available sequence contained numerous ambiguities. For the members of the $M$. mycoides-cluster - for which differences between $r r n \mathrm{~A}$ and rrn $\mathrm{B}$ have been published [27] - both sequences were used. For some Mycoplasma spp. only a partial sequence of the 16S rDNA was available. For these sequences, nucleotides were added to the 5 ' and/or 3 ' ends to generate fragments of expected length. These lengths and the choice of the nucleotides added were based on a 16S rDNA consensus sequence obtained by alignment of the complete $M y c$ oplasma 16S rDNA sequences available in Genbank using Clustal W. The restriction sites and the exact size of the
ARDRA fragments were calculated using Vector NTI Advance V9.0 (Invitrogen) and BioNumerics V3.5 (Applied-Maths, Belgium).

By way of illustration, a dendrogram, based on ARDRA patterns, was constructed using the Unweighted Pair Group Method with Arithmetic Means (UPGMA) using $1 \%$ tolerance (i.e. bands that differ about 7 nucleotides or less are considered identical) and taking only fragments from 80 to 800 nucleotides into account.

\section{Results}

For all Mycoplasma spp., the theoretical AluI,BfaI and $H p y$ F10VI restriction patterns were calculated [see Additional file 1] and are represented in Figure 1, 2, 3. For a number of species, ARDRA was carried out in the laboratory to confirm the in silico obtained results and to check the validity of the technique for identification. ARDRA profiles obtained with $A l u \mathrm{I}$ and $B f a \mathrm{I}$ are shown in Figure 4 and Figure 5, respectively. For a further verification of the technique and for the remaining 9 species that could not be identified with $A l u$ I or $B f a I$ alone, ARDRA was also performed with $H p y$ F10VI (Figure 6, 7). 


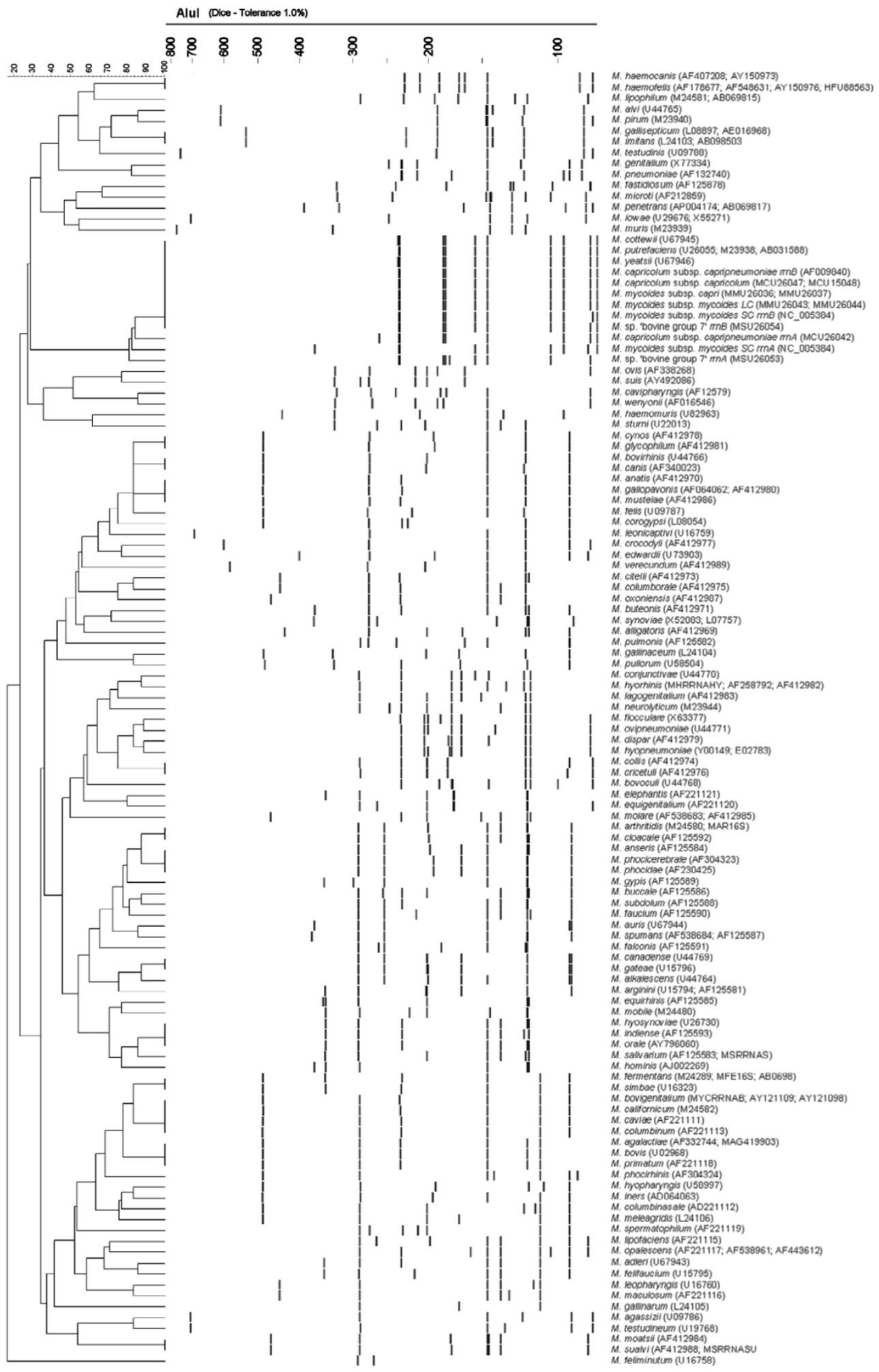

Figure I

Theoretical ARDRA patterns after in silico digestion with Alul for all currently recognized Mycoplasma spp. Patterns are clustered using UPGMA (Bionumerics V3.5) by way of illustration. The Genbank-accession numbers used are listed together with species name. 


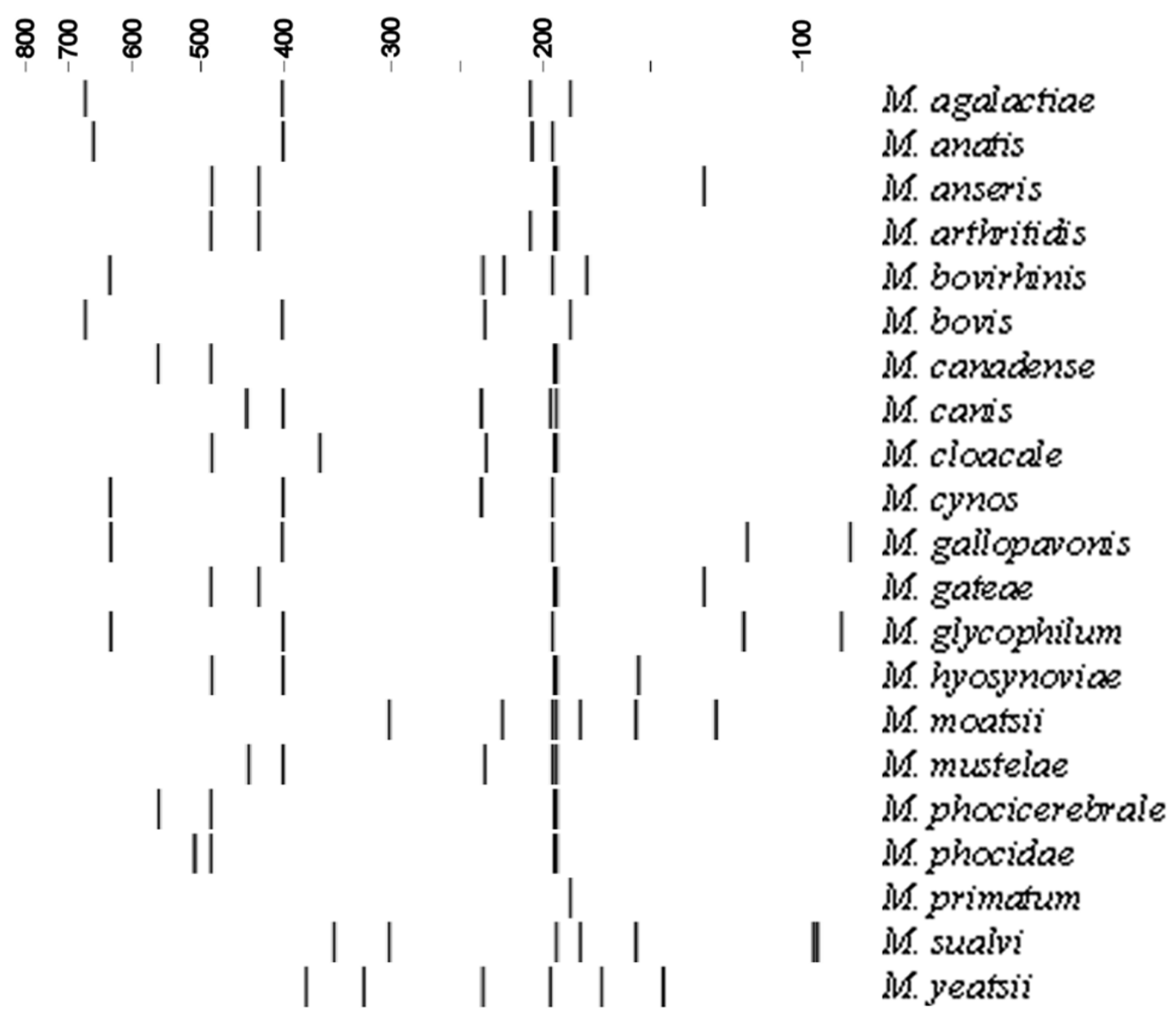

Figure 2

Calculated ARDRA profiles of Mycoplasma spp. that can be differentiated using Bfal, but had undistinguishable Alul restriction profiles.

Two of the four M. columbinum strains showed an unpredicted ARDRA pattern after restriction with AluI. Since the sum of all bands was higher than the length of the 16S sequence, a difference between the $2 \mathrm{rrn}$ operons was expected. This was verified by sequence analysis, which revealed an ambiguity at position 997 (i.e. position 1007 in the E. coli numbering), pointing to the presence of AGCT in one and AGTT in the other operon. As such, a restriction site for $A l u \mathrm{I}$ in one operon will lack in the other operon and will lead to a mixture of ARDRA profiles. Also for the strains of the M. mycoides-cluster the published sequences of both $\mathrm{rrn}$ operons were taken into account [27]. By superimposition of the restriction profiles of both $r r n \mathrm{~A}$ and $r r n \mathrm{~B}$, the correct, expected profiles were obtained. However, a faint band of approximately 370 nucleotides was observed in the HpyF10VI restriction profile of $M$. capricolum subsp. capripneumoniae, indicating a partial restriction at position 1082 of the rrnA gene (Fig- 


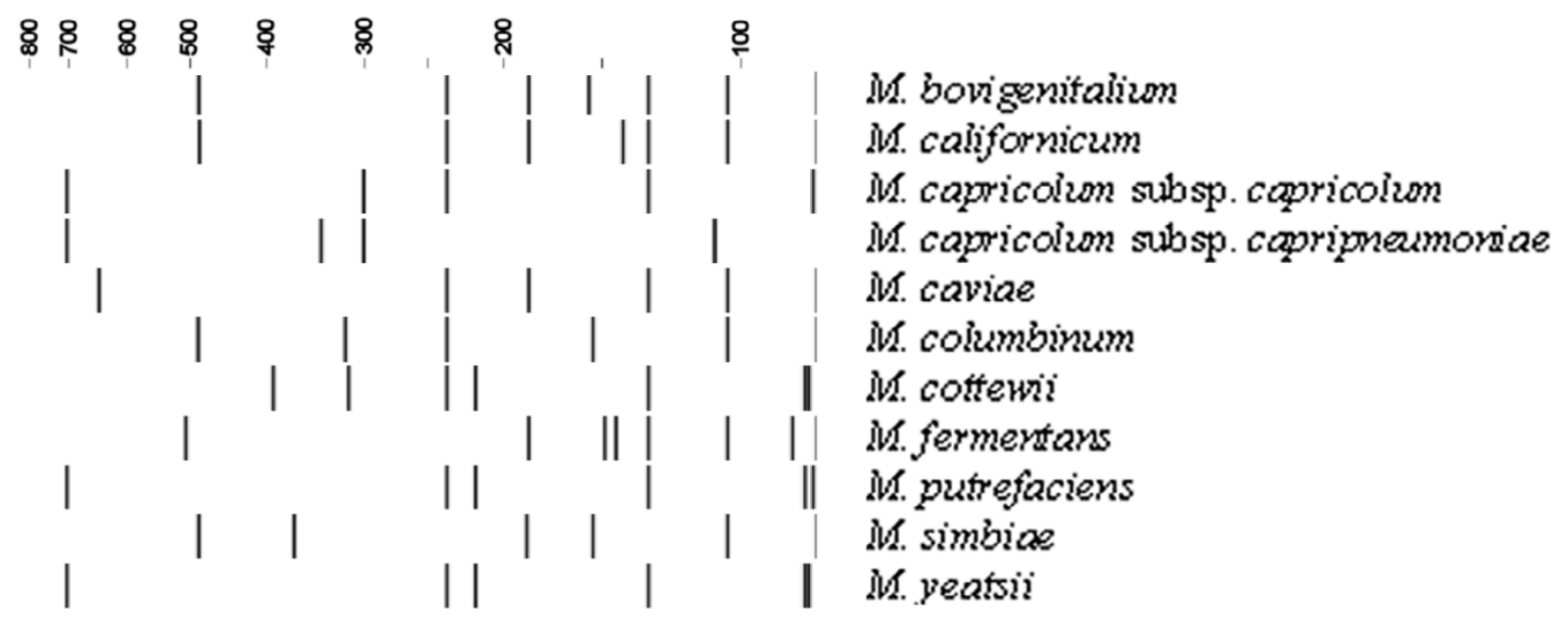

\section{Figure 3}

Calculated ARDRA profiles of Mycoplasma spp. that can be differentiated using HpyFIOVI, but had undistinguishable Alul restriction profiles. The restriction pattern of $M$. capricolum subsp. capricolum represents the not included members of the $M$. mycoides-cluster as well.
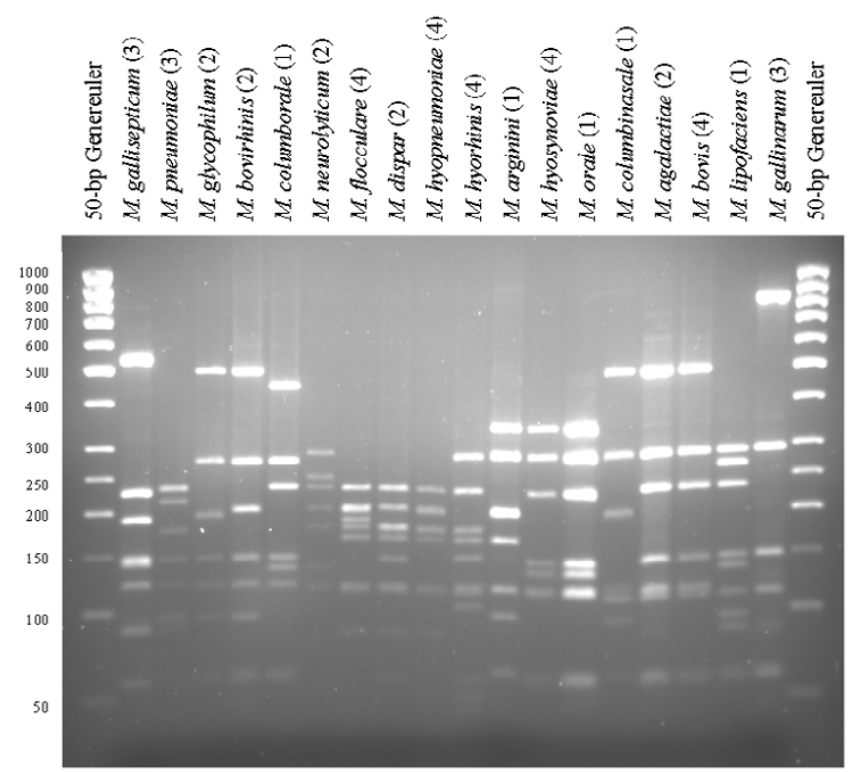

Figure 4

ARDRA profiles after restriction with Alul of 18 different Mycoplasma species. Since all samples of the same species gave identical restriction patterns, the number of strains tested for each species is indicated in parenthesis. A Generuler 50-bp ladder (Fermentas) was used as size-marker.
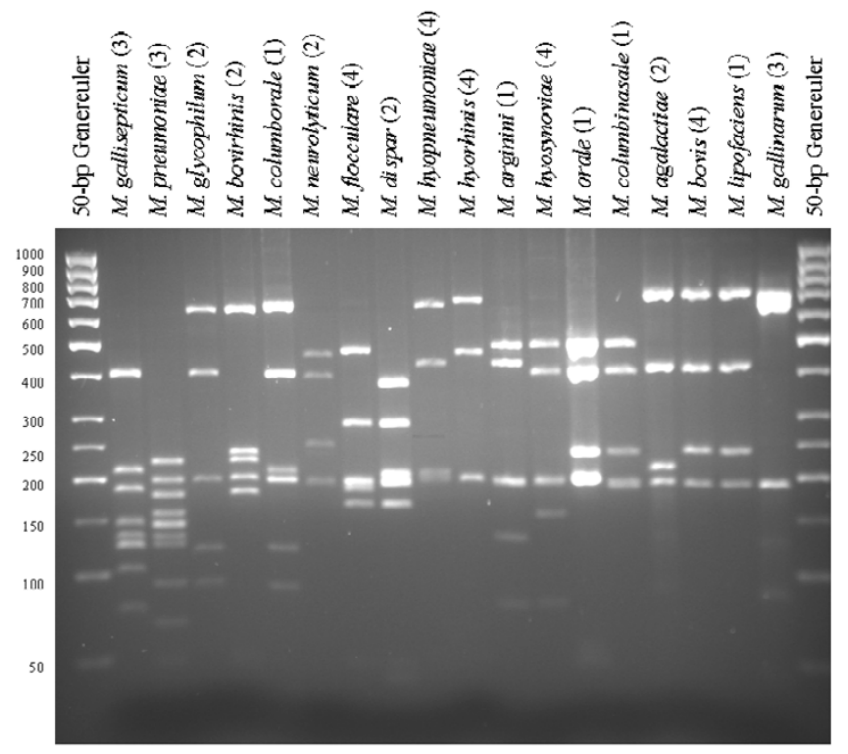

Figure 5

ARDRA profiles after restriction with $B f a l$ of 18 different Mycoplasma species. Since all samples of the same species gave identical restriction patterns, the number of strains tested for each species is indicated in parenthesis. A Generuler 50-bp ladder (Fermentas) was used as size-marker. 


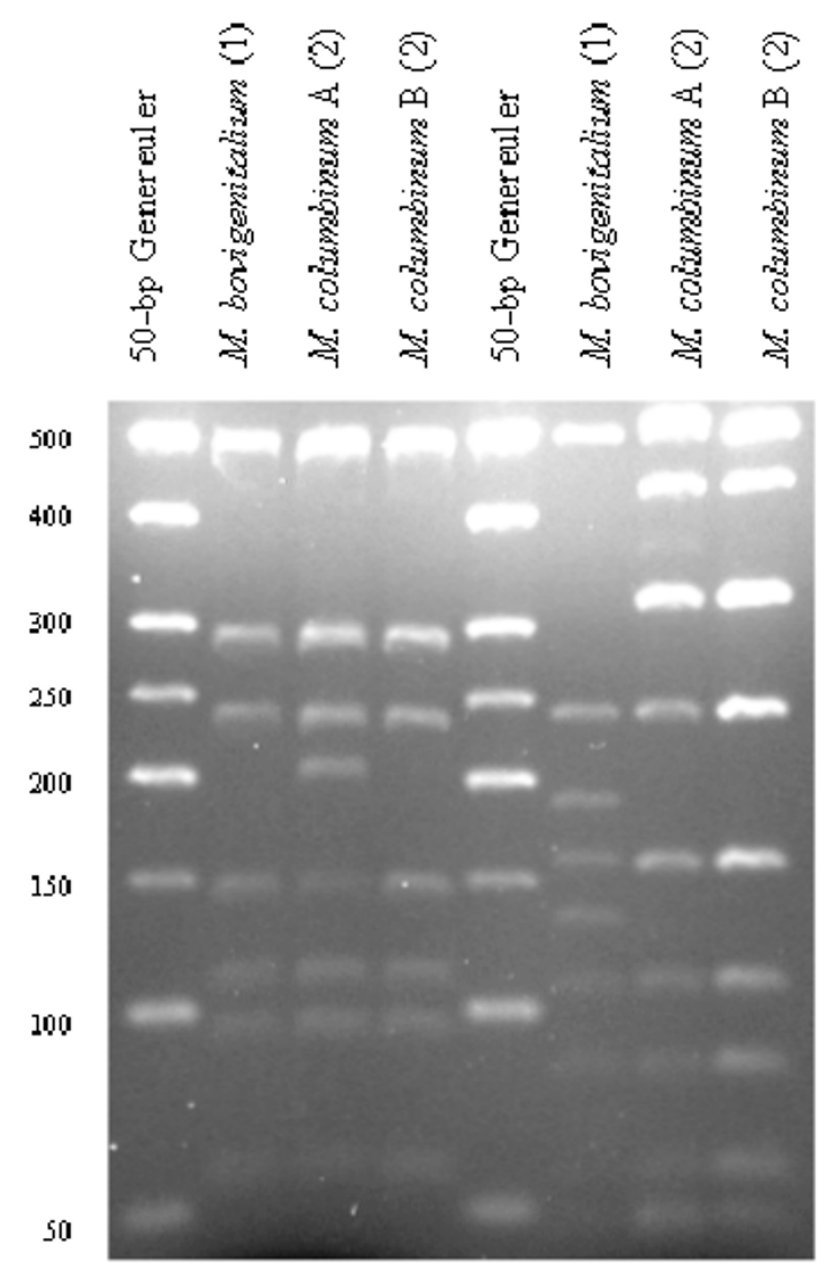

Figure 6

ARDRA profiles after restriction with Alul (left) or HpyFIOVI (right) of $M$. bovigenitalium and of $M$. columbinum. A Generuler 50-bp ladder (Fermentas) was used as size-marker. The number of strains tested for each species is indicated in parenthesis.

ure 7). For all other samples, profiles were identical to the calculated restriction profiles using only one consensus sequence of the Genbank entries.

A few species could not be differentiated with the three suggested enzymes and for these, other enzymes were selected. M. cricetuli and M. collis, which have 16S rRNA operons that are $99.8 \%$ identical, can be differentiated using Hpy $188 \mathrm{III}$. This enzyme cuts the $16 \mathrm{~S}$ rDNA of M. collis 7 times, while restriction takes place only 6 times in the $16 S$ rRNA gene of M. cricetuli. Also the restriction enzyme EarI can be used, since it only restricts the 16S rRNA gene of $M$. cricetuli. The very related $M$. imitans and M. gallisep-

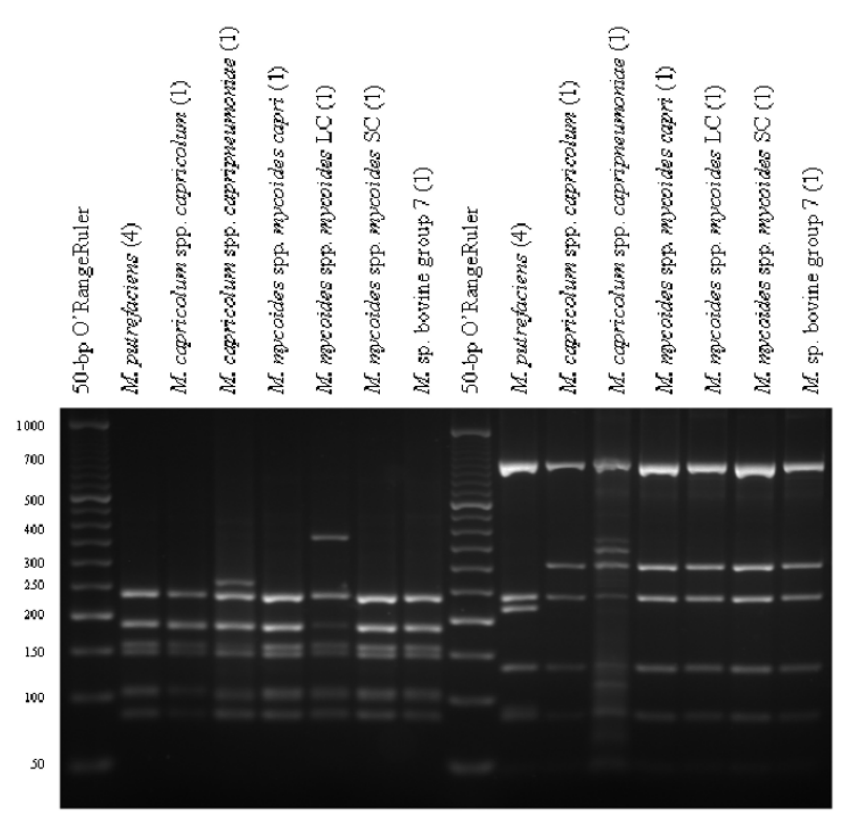

Figure 7

ARDRA profiles of $M$. putrefaciens and the $M$. mycoides cluster after restriction with Alul (left) and HpyFIOVI (right). The expected band sizes for both rrn operons are indicated in Additional file I. An O'RangeRuler 50-bp ladder (Fermentas) was used as size-marker. The number of strains tested for each species is indicated in parenthesis.

ticum could be differentiated using MseI or HindII. The restriction enzyme BstUI could be used to differentiate the otherwise indistinguishable $M$. haemocanis (2 restriction sites) and M. haemofelis (3 restriction sites). The determined $16 \mathrm{~S}$ rDNA sequence of $M$. orale was almost identical to the 16S rDNA of $M$. indiense and specific restriction enzymes, like BsaJI or EcoHI, were necessary to differentiate these species. In case of the very related members of the mycoides-cluster, the differentiation is more complicated and a whole series of restrictions are needed. Based on the occurrence of different restriction sites, it is however theoretically possible to correctly identify these species as well, using only commercially available restriction endonucleases (Table 2).

\section{Discussion}

Identification of mycoplasmas still largely relies on serological tests, but owing to the limited availability of quality-controlled sera, the high number of species, the serological cross-reaction between related species and the great variability in the surface antigens of different strains [28], newer techniques are needed. Sequence analysis of the 16S rRNA genes proved a useful tool to identify species, but the need for expensive equipment makes the 
Table 2: Number of restriction sites for the members of the $M$. mycoides-cluster

\begin{tabular}{|c|c|c|c|c|c|c|}
\hline \multirow[b]{2}{*}{$\begin{array}{c}\text { Restriction } \\
\text { endonuclease }\end{array}$} & \multicolumn{6}{|c|}{ Mycoplasma species } \\
\hline & $\begin{array}{l}\text { Mycoplasma sp. } \\
\text { bovine group } 7\end{array}$ & $\begin{array}{l}\text { M. mycoides ssp. } \\
\text { mycoides LC }\end{array}$ & $\begin{array}{l}\text { M. mycoides ssp. } \\
\text { capri }\end{array}$ & $\begin{array}{l}\text { M. mycoides ssp. } \\
\text { mycoides SC }\end{array}$ & $\begin{array}{l}\text { M. capricolum ssp. } \\
\text { capripneumoniae }\end{array}$ & $\begin{array}{l}\text { M. capricolum ssp. } \\
\text { capricolum }\end{array}$ \\
\hline Bbvl & 4 & 4 & 4 & 4 & $4 / 2$ & 4 \\
\hline HруСH4III & 3 & 4 & 4 & 3 & 3 & 3 \\
\hline HpyFIOVI & 5 & 5 & 5 & 5 & $5 / 4$ & 5 \\
\hline Maelll & 5 & 5 & 5 & 4 & 5 & 5 \\
\hline Mboll & $3 / 5^{a}$ & 3 & 3 & 3 & 3 & $3 / 4$ \\
\hline Tsp509| & 4 & 4 & 4 & $4 / 5$ & 4 & 4 \\
\hline
\end{tabular}

a Two values indicate differences between $r$ A And rrnB, based on the Genbank accession numbers indicated in I.

technique less favorable for routine diagnosis. In this study, we showed that theoretically all Mycoplasma spp. are distinguishable using ARDRA. The in silico determined discriminative power was confirmed in the laboratory and even closely related Mycoplasma spp. could be identified correctly, as exemplified by the restriction with AluI and $B f a \mathrm{I}$ of M. agalactiae and M. bovis.

We used universal primers to amplify the entire 16S rDNA to obtain a maximum discriminatory power. Working with universal primers implies that interference from other bacteria is to be expected when starting from clinical samples [29], especially when mycoplasmas are not abundantly present. The use of mycoplasma-specific primers binding to internal regions of the 16S rRNA genes may be helpful and result in a higher specificity as was already proposed by others [20,30]. However, care must be taken since the discriminatory power will decrease if primers are chosen in such a way that less restriction sites are present in the amplification products. Alternatively, McAuliffe et al. [31] proposed a selective enrichment step for 24 hours in Eaton's-medium before amplification of $16 \mathrm{~S}$ sequences to identify Mycoplasma spp. Also Kiss et al. [16] used ARDRA to identify three avian Mycoplasma species after 48 hours of incubation in Frey media. These suggested approaches may solve most problems, but may still be insufficient for mixed Mycoplasma cultures. The presence of more than one Mycoplasma species in clinical samples will lead to complex patterns, which are not easily resolved.

Differences between $r r n$ operons have been reported in several bacterial classes, but the level of sequence heterogeneity was recently shown to be lower than expected [32]. It is therefore reasonable to assume that $\mathrm{rrn}$ operons tend to evolve in concert [33]. For some bacterial species a high level of $16 \mathrm{~S}$ rDNA sequence heterogeneity has been described [34,35], while for Mycoplasma species, which possess no more than $2 \mathrm{rrn}$ operons, only some micro-het- erogeneity (i.e. scattered sequence variation between highly related rRNA genes) has been reported [27,36,37]. Besides, most differences between the two operons will not lead to altered restriction sites and will not influence the ARDRA patterns. In case a mutation is located within one of both restriction recognition sites, as was shown in particular for M. columbinum, restriction will most likely yield an unknown ARDRA profile, rather than lead to a false identification. Moreover, this aberrant pattern can be included in the identification scheme. The significance of the C1007T transition (E. coli numbering) present in two of the four $M$. columbinum strains is still unknown, but was shown in some strains of E. coli as well [33]. Also, in agreement with an earlier report [27], many differences between the rrnA and $r r n \mathrm{~B}$ sequences were observed for members of the M. mycoides cluster. Nevertheless, the combined restriction profiles of both $\mathrm{rrn}$ sequences resulted in expected patterns with exception of a faint band seen for $M$. capricolum subsp. capripneumoniae after restriction with $H p y \mathrm{~F} 10 \mathrm{VI}$. The reason for this partial restriction is unknown since purifying the PCR product, increasing the enzyme concentration, or lengthening the incubation period made no difference (data not shown). In any case, identification based on ARDRA was shown complex for these very related species and other techniques - like serological tests independent of the $16 \mathrm{~S}$ rDNA sequences [8] - may be more suitable. However, the extra band visible for M. mycoides subsp. mycoides SC after restriction with $A l u \mathrm{I}$ was shown sufficiently stable to be used for identification [38] and the value of ARDRA using PstI was also reported for M. capricolum subsp. capripneumoniae [36]. Although the 16S rDNA sequences of these species may be almost identical, ARDRA is able to emphasize the few differences present without the need of extensive 16S rDNA sequence analysis or other tests [19,38-40]. Also for other species with nearly identical $16 \mathrm{~S}$ rDNA sequences (99.5\% identity for M. haemocanis and M. haemofelis; $99.7 \%$ for M. gallisepticum and M. imitans; $98.9 \%$ for $M$. orale and $M$. indiense, and $99.8 \%$ for $M$. 
criteculi and M. collis), it was calculated that restriction analysis with a single additional enzyme would result in different restriction patterns and therefore to a correct identification.

\section{Conclusion}

Restriction digestion with AluI of the amplified 16S rDNA can be used to differentiate between 73 of the 116 described Mycoplasma species and subspecies. An additional restriction with $B f a \mathrm{I}$ or $H p y \mathrm{~F} 10 \mathrm{VI}$ enables the identification of another 31 species and subspecies. Also the remaining 12 species can be differentiated, with the use of additonal enzymes, although other techniques may be preferred for some members of the M. mycoides-cluster.

The simplicity and the general applicability of ARDRA make it possible to implement this technique in most laboratories with basic molecular biology equipment.

\section{List of abbreviations}

ARDRA amplified rDNA restriction analysis

ITS intergenic spacer(s)

CIRAD Agricultural Research Centre for International Development (Montpellier, France)

DFVF Danish Institute for Food and Veterinary Research (Copenhagen, Denmark)

UPGMA Unweighted Pair Group Method with Arithmatic Means

\section{Competing interests}

The author(s) declare that they have no competing interests.

\section{Authors' contributions}

TS collected and analyzed most of the data and was principal writer of the manuscript. TDB participated in the initial in silico data analysis, while RV helped in the correct identification of the species. JV, PB, DM, JP, and AdK COdrafted the manuscript. FH participated in the discussion of the data, participated in proofreading and management. MV conceived the study and revised the manuscript critically. All authors made contributions, read and approved the final manuscript.

\section{Additional material}

\section{Additional File 1}

Overview of the restriction fragments (and corresponding restriction sites) after ARDRA with AluI, BfaI and HpyF10VI for all current 116 Mycoplasma species and subspecies. The restriction enzymes needed to obtain a correct identification are marked in bold. The fragments are listed according to their size. Based upon available $16 S \mathrm{rDNA}$ sequences, ARDRA profiles were calculated for AluI, BfaI and HpyF10VI for all currently acknowledged Mycoplasma species. For these restriction enzymes, the file gives a detailed overview of the in silico determined restriction sites as well as the size of the restriction fragments. Click here for file

[http://www.biomedcentral.com/content/supplementary/14712334-5-46-S1.doc]

\section{Acknowledgements}

This work was supported by a grant of the Federal Service of Public Health, Food Chain Safety and Environment (Grant number S-6I36).

The authors thank Sara Tistaert for skilful technical assistance.

\section{References}

I. Saglio PHM, Whitcomb RF: Diversity of wall-less prokaryotes in plant vascular tissue, fungi, and invertebrate animals. In The mycoplasmas: plant and insects mycoplasmas Volume III. Edited by: Barile MF, Razin S, Whitcomb RF and Tully JG. London, Academic Press, Inc.; | $979:|-3|$.

2. Erno H, Peterslund K: Growth precipitation test. In Methods in Mycoplasmology: Mycoplasma Characterization Volume I. Edited by: Razin S and Tully JG. , Academic Press; 1983:489-492.

3. May JD, Branton SL: Identification of Mycoplasma isolates by ELISA. Avian Dis 1997, 41:93-96.

4. Djordjevic SP, Eamens G], Romalis LF, Saunders MM: An improved enzyme linked immunosorbent assay (ELISA) for the detection of porcine serum antibodies against Mycoplasma hyopneumoniae. Vet Microbiol 1994, 39:26 I-273.

5. Bencina $D$, Bradbury JM: Combination of immunofluorescence and immunoperoxidase techniques for serotyping mixtures of Mycoplasma species. J Clin Microbiol 1992, 30:407-4I0.

6. Thomas $C B$, Sharp P: Detection of antigenic variation among strains of Mycoplasma gallisepticum by enzyme-linked immunosorbent inhibition assay (ELISIA) and Western blot analysis. Avian Dis 1988, 32:748-756.

7. Rawadi G, Dussurget O: Genotypic methods for diagnosis of mycoplasmal infections in humans, animals, plants and cell cultures. Biotechnol Genet Eng Rev 1998, 15:5I-78.

8. Bradbury JM: International committee on systematic bacteriology, subcommittee on the taxonomy of Mollicutes. Int J Syst Evol Microbiol 200 I, 5 I :2227-2230.

9. Woese CR, Maniloff J, Zablen LB: Phylogenetic analysis of the mycoplasmas. Proc Natl Acad Sci U S A 1980, 77:494-498.

10. McAuliffe L, Ellis RJ, Ayling RD, Nicholas RA: Differentiation of Mycoplasma species by 165 ribosomal DNA PCR and denaturing gradient gel electrophoresis fingerprinting. J Clin Microbiol 2003, 4I:4844-4847.

II. Harasawa R, Mizusawa H, Nozawa K, Nakagawa T, Asada K, Kato I: Detection and tentative identification of dominant Mycoplasma species in cell cultures by restriction analysis of the 16S-23S rRNA intergenic spacer regions. Res Microbiol 1993, 144:489-493.

12. Harasawa R, Kanamoto Y: Differentiation of two biovars of Ureaplasma urealyticum based on the I6S-23S rRNA intergenic spacer region. J Clin Microbiol 1999, 37:4135-4I38.

13. Daffonchio D, Cherif A, Brusetti L, Rizzi A, Mora D, Boudabous A, Borin S: Nature of polymorphisms in I6S-23S rRNA gene 
intergenic transcribed spacer fingerprinting of Bacillus and related genera. Appl Environ Microbiol 2003, 69:5 I 28-5I37.

14. Chalker VJ, Owen WM, Paterson CJ, Brownlie J: Development of a polymerase chain reaction for the detection of Mycoplasma felis in domestic cats. Vet Microbiol 2004, 100:77-82.

15. Garcia M, Jackwood MW, Levisohn S, Kleven SH: Detection of Mycoplasma gallisepticum, M. synoviae, and $M$. iowae by multi-species polymerase chain reaction and restriction fragment length polymorphism. Avian Dis 1995, 39:606-6I6.

16. Kiss I, Matiz K, Kaszanyitzky E, Chavez Y, Johansson KE: Detection and identification of avian mycoplasmas by polymerase chain reaction and restriction fragment length polymorphism assay. Vet Microbiol 1997, 58:23-30.

17. Fan HH, Kleven SH, Jackwood MW, Johansson KE, Pettersson B, Levisohn S: Species identification of avian mycoplasmas by polymerase chain reaction and restriction fragment length polymorphism analysis. Avian Dis 1995, 39:398-407.

18. Criado-Fornelio A, Martinez-Marcos A, Buling-Sarana A, Barba-Carretero JC: Presence of Mycoplasma haemofelis, Mycoplasma haemominutum and piroplasmids in cats from southern Europe: a molecular study. Vet Microbiol 2003, 93:307-3I7.

19. Bolske G, Mattsson JG, Bascunana CR, Bergstrom K, Wesonga H, Johansson KE: Diagnosis of contagious caprine pleuropneumonia by detection and identification of Mycoplasma capricolum subsp. capripneumoniae by PCR and restriction enzyme analysis. J Clin Microbiol I996, 34:785-79I.

20. Deng S, Hiruki C, Robertson JA, Stemke GW: Detection by PCR and differentiation by restriction fragment length polymorphism of Acholeplasma, Spiroplasma, Mycoplasma, and Ureaplasma, based upon I6S rRNA genes. PCR Methods Appl 1992, I:202-204.

21. Bolske G: Survey of Mycoplasma infections in cell cultures and a comparison of detection methods. Zentralbl Bakteriol Mikrobiol Hyg $[A]$ 1988, 269:331-340.

22. Razin S, Tully JG: Methods in Mycoplasmology. In Mycoplasma Characterization Volume I. , Academic Press; 1983:504

23. Friis NF, Ahrens $\mathrm{P}$, Larsen $\mathrm{H}$ : Mycoplasma hyosynoviae isolation from the upper respiratory tract and tonsils of pigs. Acta Vet Scand 1991, 32:425-429.

24. Kobisch M, Friis NF: Swine mycoplasmoses. Rev Sci Tech 1996, 15:1569-1605.

25. Edwards U, Rogall T, Blocker H, Emde M, Bottger EC: Isolation and direct complete nucleotide determination of entire genes. Characterization of a gene coding for 165 ribosomal RNA. Nucleic Acids Res 1989, 17:7843-7853.

26. Miles R, Nicholas R: Mycoplasma protocols. In Methods in Molecular Biology Volume 104. Edited by: Walker JM. Totowa, New Jersy, Humana Press; 1998:330.

27. Pettersson B, Leitner T, Ronaghi M, Bolske G, Uhlen M, Johansson KE: Phylogeny of the Mycoplasma mycoides cluster as determined by sequence analysis of the 16S rRNA genes from the two rRNA operons. J Bacteriol 1996, I78:4|3|-4|42.

28. Rosengarten R, Yogev D: Variant colony surface antigenic phenotypes within mycoplasma strain populations: implications for species identification and strain standardization. J Clin Microbiol 1996, 34:149-158.

29. Conrads G, Flemmig TF, Seyfarth I, Lampert F, Lutticken R: Simultaneous detection of Bacteroides forsythus and Prevotella intermedia by I6S rRNA gene-directed multiplex PCR. J Clin Microbiol 1999, 37:1621-1624.

30. Blanchard A, Gautier M, Mayau V: Detection and identification of mycoplasmas by amplification of rDNA. FEMS Microbiol Lett 1991, 65:37-42.

31. McAuliffe L, Hatchell FM, Ayling RD, King Al, Nicholas RA: Detection of Mycoplasma ovipneumoniae in Pasteurella-vaccinated sheep flocks with respiratory disease in England. Vet Rec 2003, 153:687-688.

32. Acinas SG, Marcelino LA, Klepac-Ceraj V, Polz MF: Divergence and redundancy of I6S rRNA sequences in genomes with multiple rrn operons. J Bacteriol 2004, | 86:2629-2635.

33. Martinez-Murcia AJ, Anton Al, Rodriguez-Valera F: Patterns of sequence variation in two regions of the I6S rRNA multigene family of Escherichia coli. Int J Syst Bacteriol 1999, $49 \mathbf{P t}$ 2:60I-6I0

34. Marchandin H, Teyssier C, Simeon De Buochberg M, Jean-Pierre H, Carriere C, Jumas-Bilak E: Intra-chromosomal heterogeneity between the four I6S rRNA gene copies in the genus Veillonella: implications for phylogeny and taxonomy. Microbiology 2003, I49:| 1493-150|.

35. Mevarech M, Hirsch-Twizer S, Goldman S, Yakobson E, Eisenberg H, Dennis PP: Isolation and characterization of the rRNA gene clusters of Halobacterium marismortui. J Bacteriol 1989 , | 7 |:3479-3485.

36. Bascunana CR, Mattsson JG, Bolske G, Johansson KE: Characterization of the I6S rRNA genes from Mycoplasma sp. strain F38 and development of an identification system based on PCR. J Bacteriol 1994, I76:2577-2586.

37. Heldtander M, Pettersson B, Tully JG, Johansson KE: Sequences of the I6S rRNA genes and phylogeny of the goat mycoplasmas Mycoplasma adleri, Mycoplasma auris, Mycoplasma cottewii and Mycoplasma yeatsii. Int / Syst Bacteriol I998, 48 Pt I:263-268.

38. Persson A, Pettersson B, Bolske G, Johansson KE: Diagnosis of contagious bovine pleuropneumonia by PCR-laser-induced fluorescence and PCR-restriction endonuclease analysis based on the I6S rRNA genes of Mycoplasma mycoides subsp. mycoides SC. J Clin Microbiol 1999, 37:38I5-382I.

39. Vilei EM, Frey J: Differential clustering of Mycoplasma mycoides subsp. mycoides SC strains by PCR-REA of the bgl locus. Vet Microbiol 2004, 100:283-288.

40. Rodriguez JL, Ermel RW, Kenny TP, Brooks DL, DaMassa AJ: Polymerase chain reaction and restriction endonuclease digestion for selected members of the "Mycoplasma mycoides cluster" and Mycoplasma putrefaciens. J Vet Diagn Invest 1997, 9:186-190.

\section{Pre-publication history}

The pre-publication history for this paper can be accessed here:

http://www.biomedcentral.com/1471-2334/5/46/prepub
Publish with Biomed Central and every scientist can read your work free of charge

"BioMed Central will be the most significant development for disseminating the results of biomedical research in our lifetime. "

Sir Paul Nurse, Cancer Research UK

Your research papers will be:

- available free of charge to the entire biomedical community

- peer reviewed and published immediately upon acceptance

- cited in PubMed and archived on PubMed Central

- yours - you keep the copyright
BiolMedcentral 